\title{
NOTES
}

\section{SAMUEL JOHNSON AND WALT WHITMAN}

In his early notes on Samuel Johnson, probably based on T. B. Macaulay's 1856 essay, ${ }^{1}$ Whitman implicitly contrasted his own self-proclaimed vigorous health, attentive politeness, and straightforward manly prose with Johnson's physical defects, rude manners, and over-elaborate style. But he also identified, even as a young man, with Johnson's long years of poverty and quest for recognition: "physically queer, scrofulous, purblind, crotchetty . . . struggled ... thirty years through all sorts of privations and starvations ... was always of coarse behaviour, - wrote in a latinized style, not simple and with unlearned instincts, but pompous \& full of polysyllables."

Late in his life, Whitman finally read James Boswell's Life of Fohnson (1791), when Thomas Harned loaned him his copy. ${ }^{3}$ Whitman's own Boswell, Horace Traubel, recorded Whitman's reactions near the beginning of what would become his nine-volume life of Whitman, and the poet used Boswell to instruct his friend about the importance of factual accuracy: "a good many of the things told by Boswell are contradicted by the notes of annotators, who intimate that this could not possibly have happened, or that, or the other, simply because the man was absent at the time, or dead." He also criticized Johnson's habit of arguing for victory: "Johnson never cared as much to meet men - learn from men - as to drive them down roughshod - to crowd them out - to crush them against the wall. ... [He] is not concerned for truth but to make an impression." ${ }^{4}$

Johnson and Whitman, two very different characters, would seem to have no significant connection. But both men were the oldest, wisest, and well-acknowledged leaders of their circle of close friends. The old widower and old bachelor, lonely and with no wife or children, had an all-too-human dependence on affectionate conviviality and comradeship. Johnson, oppressed by melancholy and fearful of solitude, enlivened his life with stimulating talk and cheered himself up in company. He craved intellectual entertainment and constantly searched (as he wrote in The Rambler) for "some kindred mind with which he could unite in confidence and friendship." ${ }^{5}$ In his self-portrait as Mr. Sober in The Idler, he stated that his "chief pleasure is conversation; there is no end of his talk or his attention; to speak or to hear is equally pleasing."

Johnson's nocturnal visits to the houses of his friends were frequent, long, and inconvenient. He feared being left alone when his friends wished to retire, kept many of them up till unconscionable hours and forced them to drink endless cups of tea, deranging (wrote one of Joshua Reynolds's biographers) "by his immobility, the domestic economy of the house."7 Reynolds understood Johnson's dislike of being alone and in a perceptive passage observed, "Solitude to him was horror; nor would he ever trust himself alone unemployed in writ- 
ing or reading. He has often begged me to accompany him home to prevent his being alone in the coach. Any company to him was better than none; by which he connected himself with many mean persons whose presence he could command." Johnson believed that isolation left him prey to troubling thoughts. As he wrote in his first sermon, "In solitude perplexity swells into distraction, and grief settles into melancholy." Always unwilling to part from company, he was eager to prolong every social event and emphatically declared: "whoever thinks of going to bed before twelve o'clock is a scoundrel." 10

Whitman's late poem, "After the Supper and Talk," written in his sixties, not long before he read Boswell's fohnson, has a poignant, even uncanny, affinity to Johnson's thoughts, feelings, and habits:

After the supper and talk —after the day is done, As a friend from friends his final withdrawal prolonging, Good-bye and Good-bye with emotional lips repeating, (So hard for his hand to release those hands-no more will they meet, No more for communion of sorrow and joy, of old and young,

A far-stretching journey awaits him, to return no more,)

Shunning, postponing severance-seeking to ward off the last word ever so little,

E'en at the exit-door turning-charges superfluous calling back-e'en as he descends the steps,

Something to eke out a minute additional—shadows of nightfall deepening, Farewells, messages lessening-dimmer the forthgoer's visage and form, Soon to be lost for aye in the darkness-loth, O so loth to depart!

Garrulous to the very last. ${ }^{11}$

Justin Kaplan, discussing this autumnal poem, calls Whitman "a grateful and contented guest" - though he is actually mournful and deeply disturbed. ${ }^{12}$ Gary Schmidgall rather condescendingly remarks that Whitman "certainly became an expert in the performance of operatically extended farewells."13 But Whitman's poem has much more self-perception, art, and feeling than these comments suggest. The poem, like a funereal tolling of bells, has eleven allusions to death: "day is done ... final withdrawal . . . no more will they meet . . . far-stretching journey . . . return no more . . . severance . . . last word . . . exit-door ... nightfall deepening . . . dimmer the visage . . . lost for aye in the darkness." Against this inevitable fate there can be only the weak prolonging withdrawal and futile "postponing severance . . . ever so little." This moving envoi to the reader-finally enlivened (in the second short sentence) by the Johnsonian and self-deprecating "garrulous"-is also a valediction to the friends who will mourn his loss.

In this farewell poem, in which he is unwilling to say farewell, Whitman opposes friendship, conversation, good will, human warmth, and shared memories - the last joys of old age (which Johnson relished in his dining clubs) - with the absolute finality of death, which will extinguish all these pleasures. His hesitant starting and stopping, his stratagems to delay departure, are reflected in the pulsating, undulating rhythm of the opening, eleven-line sentence, and in the contrast between the first and last half of many long lines. 
Whitman does not depend on the salvation of medicine, the consolation of philosophy or the rewards of religion. He does not express John Keats's longing for oblivion in "Ode to a Nightingale" or Dylan Thomas's fury about extinction in "Do Not Go Gentle into That Good Night." Whitman is going on a long journey but does not, as in John Donne's "A Valediction: Forbidding Mourning," promise an eventual reappearance. More like Hamlet, he is leaving for "The undiscovered country, from whose bourn / No traveler returns." 14

Berkeley, California

JEFFREY MEYERS

\section{NOTES}

1 Macaulay's essay on Johnson appeared in the Encyclopedia Britannica (6th edition) in 1856 and was reprinted in Harper's Magazine 14 (March 1857), 483-497.

2 Notebooks and Unpublished Prose Manuscripts, ed. Edward Grier (New York: New York University Press, 1984), 5:1788.

3 Horace Traubel, With Walt Whitman in Camden (various publishers, 1905-1961), 1:38. Available on the Walt Whitman Archive (www.whitmanarchive.org).

4 Traubel, 1:272.

5 Samuel Johnson, Yale Edition of the Works of Samuel Fohnson, ed. W.J. Bate and Albrecht Strauss (New Haven: Yale University Press, 1969), 5:86.

6 Samuel Johnson, Yale Edition of the Works of Samuel Fohnson, ed. W. J. Bate, John Bullitt, and L. F. Powell (New Haven: Yale University Press, 1963), 2:97.

7 Ian McIntyre, foshua Reynolds (London: Allen Lane, 2003), 140.

8 Sir Joshua Reynolds, Portraits, ed. Frederick Hilles (New York: McGraw-Hill, 1952), 76.

9 Samuel Johnson, Yale Edition of the Works of Samuel Fohnson, ed. Jean Hagstrum and James Gray (New Haven: Yale University Press, 1978), 14:3.

10 James Boswell, Life of Fohnson, ed. G.B. Hill and L.F. Powell (Oxford: Clarendon, 1934), $3: \ln 2$.

11 Leaves of Grass: Comprehensive Reader's Edition, ed. Harold W. Blodgett and Sculley Bradley (New York: New York University Press, 1965), 536. Robert Frost, another elderly widower, was also reluctant to retire for the evening and loved to protract his late-night talks. When a younger friend walked him home after midnight, Frost would insist on walking the friend home, and the friend, of course, would then have to walk back home with Frost.

12 Justin Kaplan, Walt Whitman: A Life (New York: Simon \& Schuster, 1980), 24.

13 Gary Schmidgall, Walt Whitman: A Gay Life (New York: Plume, 1998), 62.

14 William Shakespeare, Hamlet, ed. Edward Hubler (New York: Signet, 1963), 94. 